\title{
ANALISA PERENCANAAN DIMENSI SALURAN DRAINASE PADA PERUMAHAN GRIYA SARTIKA RESIDENCE KALIDONI PALEMBANG
}

\author{
Ahmad Hidayat ${ }^{1)}$, Alfius Luahambowo' \\ ${ }^{1,2)}$ Teknik Sipil Universitas Tamansiswa Palembang \\ Jalan Tamansiswa No. 261.Palembang kode pos 30126 \\ E-mail : hidayat_a20@yahoo.com
}

\begin{abstract}
Abstrak
Desain dan rencana saluran drainase perumahan yang dilakukan oleh pihak deveoper sering kali dilakukan tanpa adanya perhitungan terlebih dahulu. Developer hanya membangun saluran drainase seadanya. Padahal keadaan ini suatu saat akan merugikan konsumen yang menempati perumahan tersebut, dikarenakan akan terjadi banjir yang akan merusak wilayah tersebut. Salah satu contohnya adalah pada Perumahan Griya Sartika Residence Kalidoni Palembang yang menjadi lokasi penelitian kami. Kondisi eksisting saluran drainase pada perumahan ini terdiri atas 2 jenis, yaitu saluran utama dengan kedalaman $35 \mathrm{~cm}$ dan lebar $55 \mathrm{~cm}$ dan saluran tambahan dengan kedalaman 20 $\mathrm{cm}$ dan lebar $40 \mathrm{~cm}$. Dalam perhitungan ini hanya menghitung limpasan air hujan belum termasuk air limbah buanga rumah tangga.
\end{abstract}

Kata Kunci : perumahan, saluran pembuangan, perencanaan saluran

\section{Pendahuluan}

Pembangunan perumahan di Palembang pada masa ini sedang mengalami peningkatan sesuai dengan peningkatan jumlah peduduk di kota Palembang. Namun pembangunan perumahan tersebut sering dibuat tidak sesuai dengan standar. Salah satunya adalah infrastruktur saluran drainase komplek yang sering dibuat tanpa memperkirakan kondisi ke depannya. Akibatnya perumahan tersebut menjadi rawan banjir di masa yang akan datang. Tentu saja dalam hal ini yang akan merasa dirugikan adalah penduduk komplek tersebut.

Untuk itu perlu adanya kajian sederhana mengenai perencanaan pembuatan saluran drainase pada perumahan, agar tidak merugikan pembeli perumahan tersebut di kemudian hari. Berdasarkan kondisi yang telah dijelaskan di atas yang melatarbelakangi penelitian ini yang mengambil tema mengenai perencanaan dimensi saluran Perumahan Griya Sartika Residence Kalidoni Palembang.

\section{A. Tujuan Penelitian}

Tujuan dari penelitian ini adalah
1. Untuk mengetahui dimensi dan kondisi eksisting saluran Perumahan Griya Sartika Residence Kalidoni Palembang

2. Untuk mendesain dimensi saluran drainase Perumahan Griya Sartika Residence Kalidoni Palembang yang ekonomis dan aman dari banjir.

\section{B. Kajian Literatur}

1. Pengertian Drainase

Drainase yang berasal dari bahasa Inggris yaitu drainage mempunyai arti mengalirkan, menguras, membuang, atau mengalihkan air. Secara umum, drainase dapat didefinisikan sebagai suatu tindakan teknis untuk mengurangi kelebihan air, baik yang berasal dari air hujan, rembesan, maupun kelebihan air irigasi dari suatu kawasan atau lahan, sehingga fungsi kawasan atau lahan tidak terganggu (Suripin, 2004).

\section{Analisis Hidrologi}

Analisis hidrologi dilakukan dengan mengolah data hidrologi. Data Hidrologi digunakan untuk menentukan besarnya debit maksimum rencana di sungai atau saluran alamiah dengan periode ulang tertentu $\left(\mathrm{Q}_{\mathrm{th}}\right)$ yang dapat dialirkan tanpa 
membahayakan lingkungan sekitar dan stabilitas sungai.

Data curah hujan dari stasiun pengamatan diolah menjadi data hujan harian maksimum rata-rata, kemudian dilakukan pemilihan distribusi dimana data dapat diolah dengan dua cara yaitu cara analisis dan cara grafis. Data hujan harian rencana ini dengan formula Dr. Mononobe dinyatakan dalam intensitas hujan. Intensitas hujan dalam periode tertentu digunakan pada perhitungan debit banjir rencana

\section{Analisis Curah Hujan Maksimum}

Analisa frekuensi curah hujan maksimum diperlukan untuk penyusunan suatu rancangan pemanfaatan air dan rancangan pengendalian banjir adalah curah hujan rata-rata di seluruh daerah yang bersangkutan, bukan curah hujan pada suatu titik tertentu. Curah hujan ini disebut curah hujan harian maksimum rerata dan dinyatakan dalam mm. Pengamatan curah hujan dilakukan pada stasiun- stasiun penakar yang terletak di dalam atau di sekitar Daerah Aliran Sungai (DAS) untuk mendapatkan curah hujan maksimum harian $\left(\mathrm{R}_{24}\right)$. Penentuan curah hujan maksimum harian $\left(\mathrm{R}_{24}\right)$ rata-rata wilayah DAS dari beberapa stasiun penakar tersebut dapat dihitung dengan metode untuk memperkirakan curah hujan dengan periode ulang tertentu antara lain :
a. Metode Distribusi Normal
b. Metode Distribusi Log Normal
c. Metode Distribusi Gumbel
d. Metode Distribusi Log Pearson Type III

\section{Penentuan Curah Hujan Harian Rencana}

Analisa curah hujan rencana ditujukan untuk mengetahui besarnya curah hujan maksimum dalam periode ulang tertentu. Hasil perhitungan hujan harian maksimum rerata kemudian dilakukan pemilihan distribusi, dimana dapat diolah dengan dua cara yaitu cara analisis dan cara grafis. Cara analisis menggunakan perbandingan parameter statistik untuk mendapatkan jenis sebaran (distribusi) yang sesuai. Cara grafis adalah dengan mengeplot di kertas probabilitas. Plotting ini kemudian harus dicek dengan melakukan uji keselarasan.

\section{Parameter Statistik}

Untuk perhitungan hujan rencana digunakan analisa frekuensi, cara yang dipakai adalah dengan menggunakan metode kemungkinan (Probability Distribution) teoritis yang ada.
Dalam penentuan metode yang akan digunakan, diperlukan syarat-syarat statistik. Syarat tersebut dapat dilihat pada tabel 2.1.

Tabel 1. Pedoman Umum Penggunaan Metode Distribusi Sebaran

\begin{tabular}{|l|l|l|}
\hline $\begin{array}{c}\text { N } \\
\mathbf{0}\end{array}$ & $\begin{array}{c}\text { Jenis } \\
\text { Distrib } \\
\text { usi }\end{array}$ & \multicolumn{1}{|c|}{ Syarat } \\
\hline 1 & Normal & $C s \approx 0, C k \approx 3$ \\
\hline 2 & $\begin{array}{l}\text { Log } \\
\text { Normal }\end{array}$ & $\begin{array}{l}C s=3 C v+C v^{3} \\
C k=C v^{8}+6 C v^{6}+15 C v^{4}+16 C v^{2}+3\end{array}$ \\
\hline 3 & Gumbel & $C s \leq 1,1396, C k \leq 5,4002$ \\
\hline 4 & $\begin{array}{l}\text { Log } \\
\text { Pearson } \\
\text { Type III }\end{array}$ & $C s<0, C v=0,3$ \\
\hline
\end{tabular}

(Soewarno, 1995)

\section{Gambaran Umum Wilayah Penelitian}

\section{Kondisi Topografi}

Kondisi topografi di perumahan Griya Sartika Residence Palembang ini merupakan daerah rendah yang menjadi salah satu faktor penyebab genangan air di perumahan Griya Sartika Residence Palembang. Disebabkan drainase pada perumahan Griya Sartika Residence Palembang tidak berfungsi dengan baik. Disamping itu drainase pada perumahan Griya Sartika Residence Palembang banyak yang tersumbat sampah rumah tangga

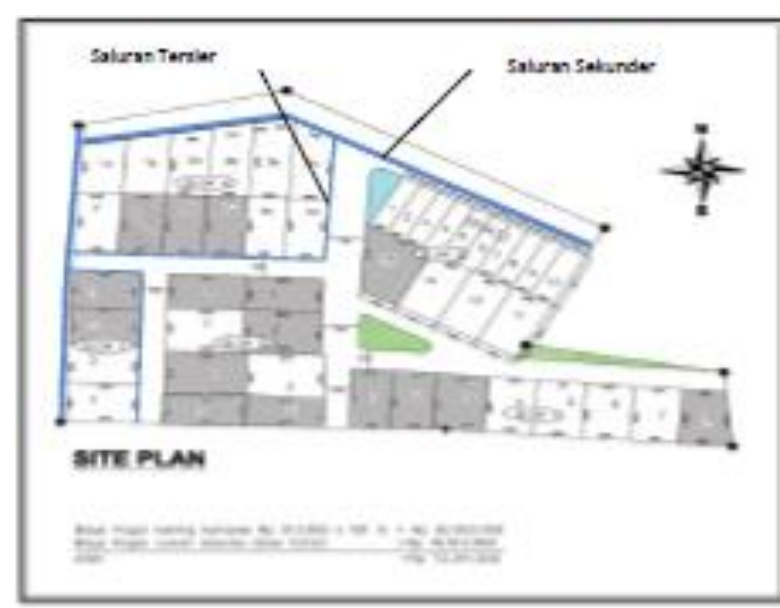

Gambar 1. Site Plan Perumahan Griya Sartika Residence

Hasil pengamatan di lokasi penelitian, pada Perumahan Griya Sartika Residence terdapat jenis ukuran saluran sekunder dan saluran tersier seperti pada gambar 2 di bawah ini. 

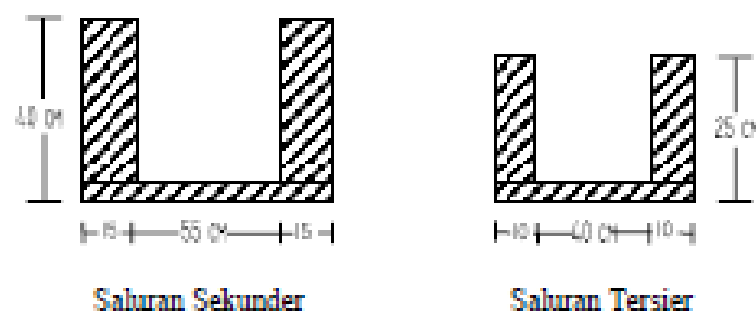

Saluran Tersier

Gambar 2. Tipe dimensi saluran drainase pada Perumahan Griya Sartika Residence

\section{Metode Penelitian}

\section{A. Metode Pengumpulan Data}

Data 2 metode pengumpulan data, yaitu data primer dan data sekunder. Data Primer berupa peneliti dapatkan dari hasil survey dan pengukuran kondisi eksisting saluran drainase ke lapangan serta wawancara yang dilaksanakan dengan penduduk di wilayah tersebut. Data primer lainnya berupa dokumentasi.

Sedangkan data sekunder yang diperlukan adalah :

1. Site Plan Perumahan

2. Data curah hujan dari BMKG

\section{B. Metode Analisa dan Pembahasan}

Analisa yang digunakan adalah :

1. Analisis hidrologi

2. Analisis curah hujan maksimum

3. Penentuan curah hujan harian

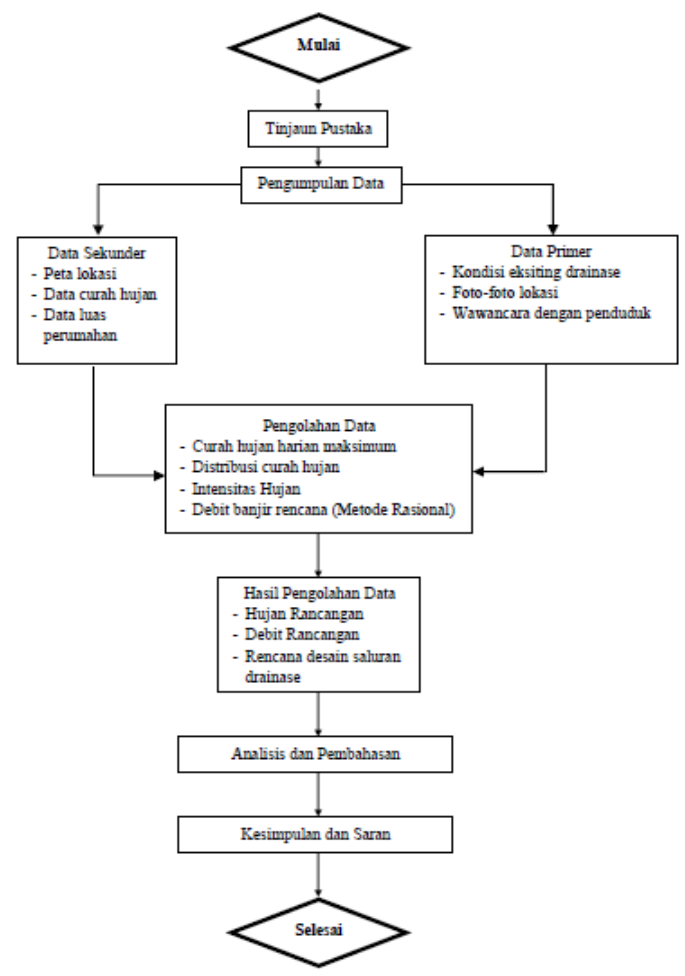

Gambar 3. Diagram Alir Penelitian

\section{Hasil dan Pembahasan}

\section{A. Analisa Frekuensi Curah Hujan}

Daerah curah hujan bersumber dari Stasiun Klimatologi yang ada di Palembang yaitu Stasiun Klimatologi Kenten Palembang. Maka didapat data curah hujan sebagai berikut :

Tabel 2. Data Curah Hujan Maksimum Bulanan Kota Palembang

\begin{tabular}{|c|c|c|c|}
\hline No & Tahun & $\boldsymbol{x}_{\boldsymbol{i}}$ & $\boldsymbol{L o g} \boldsymbol{x}_{\boldsymbol{i}}$ \\
\hline 1 & 2009 & 140 & 2,15 \\
\hline 2 & 2010 & 146 & 2,16 \\
\hline 3 & 2011 & 135 & 2,13 \\
\hline 4 & 2012 & 46 & 1,66 \\
\hline 5 & 2013 & 89 & 1,95 \\
\hline 6 & 2014 & 151 & 2,18 \\
\hline 7 & 2015 & 95 & 1,98 \\
\hline 8 & 2016 & 115 & 2,06 \\
\hline 9 & 2017 & 134 & 2,13 \\
\hline 10 & 2018 & 85 & 1,93 \\
\hline
\end{tabular}

(Sumber : Stasiun Klimatologi Kenten Palembang)

\section{B. Perhitungan Curah Hujan Rencana dengan metode distribusi Nornal}

Tabel 3. Perhitungan Curah Hujan Rencana Distribusi Normal

\begin{tabular}{|c|c|c|c|c|c|c|}
\hline $\mathbf{N o}$ & $\mathbf{T a h u n}$ & $\mathbf{x}_{\mathbf{i}}$ & $\begin{array}{c}\left(\mathbf{x}_{\mathbf{i}}-\right. \\
\left.\mathbf{x}_{\mathbf{r}}\right)\end{array}$ & $\left(\mathbf{x}_{\mathbf{i}}-\mathbf{x}_{\mathbf{r}}\right)^{\mathbf{2}}$ & $\left(\mathbf{x}_{\mathbf{i}}-\mathbf{x}_{\mathbf{r}}\right)^{\mathbf{3}}$ & $\left(\mathbf{x}_{\mathbf{i}}-\mathbf{x}_{\mathbf{r}}\right)^{\mathbf{4}}$ \\
\hline 1 & 2009 & 140 & 26,40 & 696,96 & 18399,74 & 485753,24 \\
\hline 2 & 2010 & 146 & 32,40 & 1049,76 & 34012,22 & 1101996,06 \\
\hline 3 & 2011 & 135 & 21,40 & 457,96 & 9800,34 & 209727,36 \\
\hline 4 & 2012 & 46 & $-67,6$ & 4569,76 & $-308915,7$ & 20882706,46 \\
\hline 5 & 2013 & 89 & $-24,6$ & 605,16 & $-14886,94$ & 366218,63 \\
\hline 6 & 2014 & 151 & 37,40 & 1398,76 & 52313,62 & 1956529,54 \\
\hline 7 & 2015 & 95 & $-18,6$ & 345,96 & $-6434,86$ & 119688,32 \\
\hline 8 & 2016 & 115 & 1,40 & 1,96 & 2,74 & 3,84 \\
\hline 9 & 2017 & 134 & 20,40 & 416,16 & 8489,66 & 173189,15 \\
\hline 10 & 2018 & 85 & $-28,6$ & 817,96 & $-23393,66$ & 669058,56 \\
\hline & $\Sigma$ & 1136 & 0,00 & 10360,4 & $-230612,8$ & 25964871,15 \\
\hline
\end{tabular}


- Rata-rata

$$
x_{r}=\frac{\sum x_{i}}{n}=\frac{1136}{10}=113,6
$$

- Standar Deviasi

$$
S_{d}=\sqrt{\frac{\sum\left(x_{i}-x_{r}\right)^{2}}{n-1}}=\sqrt{\frac{10360,40}{9}}=33,9286
$$

- Koefisien Variasi

$$
C_{v}=\frac{S_{d}}{x_{r}}=\frac{33,9286}{113,6}=0,2986
$$

- Koefisien Skewness

$$
C_{s}=\frac{n \sum\left(x_{i}-x_{r}\right)^{3}}{(n-1)(n-2)(s d)^{3}}=\frac{-2306128,8}{2812117,85}=-0,82
$$

- Koefisien Kurtosis

$C_{k}=\frac{n^{2} \sum\left(x_{i}-x_{r}\right)^{4}}{(n-1)(n-2)(n-3)(s d)^{4}}=\frac{2596487115}{667880193,00}=3,887654 \begin{gathered}\text { Tabel } 5 . \text { Perhitungan } \mathrm{X}^{2} \mathrm{C}_{\mathrm{r}} \\ \text { (Sumber }: \text { Perhitungan) }\end{gathered}$

\begin{tabular}{|c|l|l|c|c|c|c|}
\hline \multicolumn{2}{|c|}{$\begin{array}{c}\text { Nilai Batas Tiap } \\
\text { Kelas }\end{array}$} & $\mathbf{E}_{\mathbf{f}}$ & $\mathbf{O}_{\mathbf{f}}$ & $\left(\mathbf{E}_{\mathbf{f}}-\mathbf{O}_{\mathbf{f}}\right)^{\mathbf{2}}$ & $\mathbf{X}^{2} \mathbf{C}_{\mathbf{r}}$ \\
\hline 28,67 & $<\mathrm{x}<$ & 60,18 & 2,3 & 1 & 1,71 & 0,742 \\
\hline 60,18 & $<\mathrm{x}<$ & 91,69 & 2,3 & 2 & 0,10 & 0,041 \\
\hline 91,69 & $<\mathrm{x}<$ & 123,21 & 2,3 & 2 & 0,10 & 0,041 \\
\hline 123,21 & $<\mathrm{x}<$ & 154,72 & 2,3 & 5 & 7,24 & 3,138 \\
\hline \multicolumn{2}{|c|}{ Jumlah } & $\mathbf{1 0}$ & $\mathbf{1 0}$ & $\boldsymbol{x}^{2}$ Hitung & $\mathbf{3 , 9 6 2}$ \\
\hline
\end{tabular}

$$
\Delta x \quad=\frac{x_{i=1}-x_{i=10}}{k-1}
$$

$$
=\frac{151-46}{3,322}
$$$$
=31,51
$$$$
x_{\text {awal }}=x_{i=10}-\frac{1}{2} \Delta x
$$$$
=46-\frac{1}{2} 31,51
$$

1. Uji Chi Kuadrat Terhadap Distribusi Normal

Tabel 4. Perhitungan Uji Chi Kuadrat

\begin{tabular}{|l|c|c|}
\hline No & Tahun & $\boldsymbol{x}_{\boldsymbol{i}}$ \\
\hline 1 & 2009 & 151 \\
\hline 2 & 2010 & 146 \\
\hline 3 & 2011 & 140 \\
\hline 4 & 2012 & 135 \\
\hline 5 & 2013 & 134 \\
\hline 6 & 2014 & 115 \\
\hline 7 & 2015 & 95 \\
\hline 8 & 2016 & 89 \\
\hline 9 & 2017 & 85 \\
\hline 10 & 2018 & 46 \\
\hline
\end{tabular}

(Sumber : Perhitungan)

- $\quad$ Menghitung Banyak Kelas

$$
\begin{aligned}
K \quad & =1+3,322 \log n \\
& =1+3,322 \log 10 \\
& =4,322
\end{aligned}
$$

Jadi banyak kelas adalah 4 kelas

- Menghitung Nila $E_{\mathrm{f}}$

$$
\begin{aligned}
E_{f} & =\frac{n}{K} \\
& =\frac{10}{4} \\
& =2,5
\end{aligned}
$$

- Derajat Kebebasan

$$
D_{k} \quad=K-(R+1)
$$$$
=4-(1+1)
$$

$=2$

Maka untuk $x^{2}$ tabel untuk $\mathrm{Dk}=2$ dan signifikan 0,05 diperoleh 5,991 (tabel nilai kritis chi square)

$x_{\text {Hitung }}^{2}=3,962$

$x_{\text {tabel }}^{2}=5,991$

Maka metode distribusi normal dapat diterima karena $x_{\text {Hitung }}^{2}<x_{\text {tabel }}^{2}$

2. Uji Smirnov Kolmogorov Terhadap Distribusi Normal

Tabel 6. Perhitungan Uji Smirnov Kolmogorov

\begin{tabular}{|c|c|c|c|c|c|c|c|}
\hline $\boldsymbol{x}_{\boldsymbol{i}}$ & $\mathbf{m}$ & $\mathbf{P}(\mathbf{x})$ & $\mathbf{P}(\mathbf{x}<)$ & $\mathbf{F}_{\mathbf{t}}$ & $\mathbf{P}^{\prime}(\mathbf{x})$ & $\mathbf{P}^{\prime}(\mathbf{x}<)$ & $\mathbf{D}$ \\
\hline 151 & 1 & 0,091 & 0,909 & 1,10 & 0,883 & 0,117 & 0,792 \\
\hline 146 & 2 & 0,182 & 0,818 & 0,95 & 0,842 & 0,158 & 0,660 \\
\hline 140 & 3 & 0,273 & 0,727 & 0,78 & 0,793 & 0,207 & 0,520 \\
\hline 135 & 4 & 0,364 & 0,636 & 0,63 & 0,754 & 0,246 & 0,390 \\
\hline 134 & 5 & 0,455 & 0,545 & 0,60 & 0,742 & 0,258 & 0,287 \\
\hline 115 & 6 & 0,545 & 0,455 & 0,04 & 0,529 & 0,471 & $-0,016$ \\
\hline 95 & 7 & 0,636 & 0,364 & $-0,5$ & 0,286 & 0,714 & $-0,350$ \\
\hline 89 & 8 & 0,727 & 0,273 & $-0,7$ & 0,207 & 0,793 & $-0,520$ \\
\hline 85 & 9 & 0,818 & 0,182 & $-0,8$ & 0,181 & 0,819 & $-0,637$ \\
\hline 46 & 10 & 0,909 & 0,091 & $-1,9$ & 0,024 & 0,976 & $-0,885$ \\
\hline \multicolumn{7}{|c|}{} \\
\hline
\end{tabular}

(Sumber : Perhitungan)

- $\quad$ Nilai Batas Tiap Kelas 
Berdasarkan tabel nilai kritis untuk uji smirnov kolmogorov

$\begin{array}{ll}\mathrm{n} & =10 \text { tahun } \\ \mathrm{D}_{\mathrm{o}}(1 \%) & =0,486 \\ \mathrm{D}_{\mathrm{o}}(5 \%) & =0,409\end{array}$

Maka metode distribusi normal dapat diterima karena $\mathrm{D}_{\max }<\mathrm{D}_{\mathrm{o}}(5 \%)$

\section{Perhitungan Curah ujan Rencana degan menggunakan Metode Distribusi Log Pearson Type III}

Tabel 7. Perhitungan Curah Hujan Rencana Distribusi Log Pearson Type III

\begin{tabular}{|c|c|c|c|c|c|c|}
\hline No & Th & $\log x$ & $\begin{array}{c}\left(\log x_{i}-\right. \\
\left.\log x_{r}\right)\end{array}$ & $\begin{array}{c}\left(\log x_{i}\right. \\
\left.\log x_{r}\right)^{2}\end{array}$ & $\begin{array}{c}\left(\log x_{i}-\right. \\
\left.\log x_{r}\right)^{3} \\
\end{array}$ & Lo \\
\hline & & & & & & \\
\hline & & & & & & \\
\hline & & & & & & \\
\hline 4 & 3 & 1,6 & & & & \\
\hline 5 & 14 & 1,95 & & & & \\
\hline 6 & & 2, & & & & \\
\hline 1 & 0 & 1,98 & & 0,0 & & \\
\hline 8 & 7 & 2,0 & & & & \\
\hline 9 & 8 & 2,13 & & & & \\
\hline 1 & & 1,93 & 0,0 & & & \\
\hline & & 20 & & & $-0,04380$ & 0 \\
\hline
\end{tabular}

(Sumber : Perhitungan)

- Rata-rata

$$
\log x_{r}=\frac{\sum \log x_{i}}{n}=\frac{20,33}{10}=2,033
$$

- Standar Deviasi

$$
S_{d}=\sqrt{\frac{\sum\left(\log x_{i}-\log x_{r}\right)^{2}}{n-1}}=\sqrt{\frac{0,228310983}{9}}=0,159273
$$

- Koefisien Variasi

$$
C_{v}=\frac{S_{d}}{x_{r}}=\frac{0,159273}{2,033}=0,078356
$$

- Koefisien Skewness $C_{s}=\frac{n \sum\left(\log x_{i}-\log x_{r}\right)^{3}}{(n-1)(n-2)(s d)^{3}}=\frac{-0,43802332}{0,29091}=-1,505$

- Koefisien Kurtosis

$$
C_{k}=\frac{n^{2} \sum\left(\log x_{i}-\log x_{r}\right)^{4}}{(n-1)(n-2)(n-3)(s d)^{4}}=\frac{1,9994}{0,3243}=6,16443
$$

1. Uji Chi Kuadrat Terhadap Distribusi Log Pearson Type III

Tabel 8. Perhitungan Uji Chi Kuadrat Terhadap Distribusi Log Pearson Type III

\begin{tabular}{|c|c|c|}
\hline No & Tahun & $\log \boldsymbol{x}_{\boldsymbol{i}}$ \\
\hline 1 & 2009 & 2,18 \\
\hline 2 & 2010 & 2,16 \\
\hline 3 & 2011 & 2,15 \\
\hline 4 & 2012 & 2,13 \\
\hline 5 & 2013 & 2,13 \\
\hline 6 & 2014 & 2,06 \\
\hline 7 & 2015 & 1,98 \\
\hline 8 & 2016 & 1,95 \\
\hline 9 & 2017 & 1,93 \\
\hline 10 & 2018 & 1,66 \\
\hline
\end{tabular}

(Sumber : Perhitungan)

- Menghitung Banyak Kelas

$$
\begin{aligned}
K \quad & =1+3,322 \log n \\
& =1+3,322 \log 10 \\
& =4,322
\end{aligned}
$$

Jadi banyak kelas adalah 4 kelas

- Menghitung Nila $E_{\mathrm{f}}$

$$
\begin{aligned}
E_{f} & =\frac{n}{K} \\
& =\frac{10}{4} \\
& =2,5
\end{aligned}
$$

- Nilai Batas Tiap Kelas

$$
\begin{aligned}
\Delta x \quad & =\frac{x_{i=1}-x_{i=10}}{k-1} \\
& =\frac{2,18-1,66}{3,322} \\
& =0,15 \\
x_{\text {awal }} \quad & =x_{i=10}-\frac{1}{2} \Delta x \\
& =1,66-\frac{1}{2} 0,15 \\
& =1,59
\end{aligned}
$$

Tabel 9 Perhitungan $\mathrm{X}^{2} \mathrm{C}_{\mathrm{r}}$

\begin{tabular}{|c|c|c|c|c|c|c|}
\hline \multicolumn{2}{|c|}{ Nilai Batas Tiap Kelas } & $\mathbf{E}_{\mathbf{f}}$ & $\mathbf{O}_{\mathbf{f}}$ & $\left(\mathbf{E}_{\mathbf{f}}-\mathbf{O}_{\mathbf{f}}\right)^{\mathbf{2}}$ & $\mathbf{X}^{\mathbf{2}} \mathbf{C}_{\mathbf{r}}$ \\
\hline 1,59 & $<\mathrm{x}<$ & 1,74 & 2,3 & 1 & 1,71 & 0,742 \\
\hline 1,74 & $<\mathrm{x}<$ & 1,90 & 2,3 & 0 & 5,33 & 2,308 \\
\hline 1,90 & $<\mathrm{x}<$ & 2,05 & 2,3 & 3 & 0,48 & 0,207 \\
\hline 2,05 & $<\mathrm{x}<$ & 2,21 & 2,3 & 6 & 13,63 & 5,904 \\
\hline \multicolumn{3}{|c|}{ Jumlah } & $\mathbf{1 0}$ & $\mathbf{1 0}$ & $\boldsymbol{x}^{2}$ Hitung & $\mathbf{9 , 1 6 1}$ \\
\hline
\end{tabular}

(Sumber : Perhitungan) 
- Derajat Kebebasan

$$
\begin{aligned}
D_{k} & =K-(R+1) \\
& =4-(2+1) \\
& =1
\end{aligned}
$$

Maka untuk $x^{2}$ tabel untuk $\mathrm{Dk}=1$ dan signifikan 0,05 diperoleh 3,891 (tabel nilai kritis chi square)

$$
x^{2} \text { Hitung }=1,200
$$$$
x^{2}{ }_{\text {tabel }}=3,891
$$

Maka metode distribusi log pearson type III dapat diterima karena $\quad x^{2}{ }_{\text {Hitung }}<x^{2}$ tabel

\begin{tabular}{|c|c|c|c|c|c|c|c|}
\hline$x_{i}$ & $\mathbf{M}$ & $\vec{P}(\mathbf{x})$ & $\mathbf{P}(\mathbf{x}<)$ & $F_{t}$ & $P^{\prime}(\mathbf{x})$ & $\mathbf{P}^{\prime}(\mathbf{x}<)$ & D \\
\hline 2,18 & 1 & 91 & 909 & 0,92 & 0,843 & 0,157 &, 752 \\
\hline 2,16 & 2 & 82 & 18 & 0,83 & 319 & 181 & 63 \\
\hline 2,15 & 3 & 0 , & 727 & 0,71 &, 783 & 217 & $, 5]$ \\
\hline 2,13 & 4 & 0,364 & 0,636 & 0,61 & 0,763 & 0,237 & 0,35 \\
\hline 2,13 & 5 & 0,455 & 0,545 & 0,59 & 0,738 & 0,262 & 0,283 \\
\hline 2,06 & 6 & 0,545 & 0,455 & 0,18 & 0,589 & 411 & 0,044 \\
\hline 1,98 & 7 & 0,636 & 54 & $-0,35$ & 0,353 & 0,647 & $-0,28$ \\
\hline 1,95 & 8 & 0,727 & 0,273 & $-0,52$ & 0,281 & 0,719 & $-0,44$ \\
\hline 1,93 & 9 & 0, & 32 & $-0,65$ & 0,247 & 753 & $-0,57$ \\
\hline 1,66 & 10 & 0,909 & 0,091 & $-2,32$ & 0,008 & 0,992 & $-0,90$ \\
\hline & & & & & & & 0,42 \\
\hline
\end{tabular}

2. Uji Smirnov Kolmogorov Terhadap Distribusi Log Pearson Type III

Tabel 10. Perhitungan Uji Smirnov Kolmogorov

(Sumber : Perhitungan)

Berdasarkan tabel nilai kritis untuk uji smirnov kolmogorov

$$
\begin{array}{ll}
\mathrm{n} & =10 \text { tahun } \\
\mathrm{D}_{\mathrm{o}}(1 \%) & =0,486 \\
\mathrm{D}_{\mathrm{o}}(5 \%) & =0,409
\end{array}
$$

Maka metode distribusi log pearson type III dapat diterima karena $\mathrm{D}_{\max }<\mathrm{D}_{\mathrm{o}}(5 \%)$

\section{Perhitungan Curah Hujan Rencana Distribusi Gumbel}

Tabel 11. Perhitungan Curah Hujan Rencana Distribusi Gumbel

\begin{tabular}{|c|c|c|c|c|c|c|}
\hline $\mathbf{N o}$ & Tahun & $\mathbf{x}_{\mathbf{i}}$ & $\left(\mathbf{x}_{\mathbf{i}}-\mathbf{x}_{\mathbf{r}}\right)$ & $\left(\mathbf{x}_{\mathbf{i}}-\mathbf{x}_{\mathbf{r}}\right)^{2}$ & $\left(\mathbf{x}_{\mathbf{i}}-\mathbf{x}_{\mathbf{r}}\right)^{\mathbf{3}}$ & $\left(\mathbf{x}_{\mathbf{i}}-\mathbf{x}_{\mathbf{r}} \mathbf{4}^{\mathbf{4}}\right.$ \\
\hline 1 & 2009 & 140 & 26,40 & 696,96 & 18399,74 & 485753,24 \\
\hline 2 & 2010 & 146 & 32,40 & 1049,76 & 34012,22 & 1101996,06 \\
\hline 3 & 2011 & 135 & 21,40 & 457,96 & 9800,34 & 209727,36 \\
\hline 4 & 2012 & 46 & $-67,6$ & 4569,76 & $-308915,7$ & 20882706,46 \\
\hline 5 & 2013 & 89 & $-24,6$ & 605,16 & $-14886,94$ & 366218,63 \\
\hline 6 & 2014 & 151 & 37,40 & 1398,76 & 52313,62 & 1956529,54 \\
\hline 7 & 2015 & 95 & $-18,6$ & 345,96 & $-6434,86$ & 119688,32 \\
\hline 8 & 2016 & 115 & 1,40 & 1,96 & 2,74 & 3,84 \\
\hline
\end{tabular}

\begin{tabular}{|c|c|c|c|c|c|c|}
\hline 9 & 2017 & 134 & 20,40 & 416,16 & 8489,66 & 173189,15 \\
\hline 10 & 2018 & 85 & $-28,6$ & 817,96 & $-23393,66$ & 669058,56 \\
\hline \multicolumn{2}{|c|}{$\boldsymbol{\Sigma}$} & $\mathbf{1 1 3 6}$ & $\mathbf{0 , 0 0}$ & $\mathbf{1 0 3 6 0 , 4 0}$ & $\mathbf{- 2 3 0 6 1 2 , 9}$ & $\mathbf{2 5 9 6 4 8 7 1 , 1 5}$ \\
\hline
\end{tabular}

(Sumber : Perhitungan)

1. Rata-rata

$$
x_{r}=\frac{\sum x_{i}}{n}=\frac{1136}{10}=113,6
$$

2. Standar Deviasi

$$
S_{d}=\sqrt{\frac{\sum\left(x_{i}-x_{r}\right)^{2}}{n-1}}=\sqrt{\frac{10360,40}{9}}=33,9286
$$

3. Koefisien Variasi

$$
C_{v}=\frac{S_{d}}{x_{r}}=\frac{33,9286}{113,6}=0,2986
$$

4. Koefisien Skewness

$$
C_{s}=\frac{n \sum\left(x_{i}-x_{r}\right)^{3}}{(n-1)(n-2)(s d)^{3}}=\frac{-2306128,8}{2812117,85}=-0,82
$$

5. Koefisien Kurtosis

$$
C_{k}=\frac{n^{2} \sum\left(x_{i}-x_{r}\right)^{4}}{(n-1)(n-2)(n-3)(s d)^{4}}=\frac{2596487115}{667880193,00}=3,887654
$$

1. Uji Chi Kuadrat Terhadap Distribusi Gumbel

Tabel 12 Perhitungan Uji Chi Kuadrat

\begin{tabular}{|c|c|c|}
\hline No & Tahun & $\boldsymbol{x}_{\boldsymbol{i}}$ \\
\hline 1 & 2010 & 151 \\
\hline 2 & 2006 & 146 \\
\hline 3 & 2005 & 140 \\
\hline 4 & 2007 & 135 \\
\hline 5 & 2013 & 134 \\
\hline 6 & 2012 & 115 \\
\hline 7 & 2011 & 95 \\
\hline 8 & 2009 & 89 \\
\hline 9 & 2014 & 85 \\
\hline 10 & 2008 & 46 \\
\hline
\end{tabular}

(Sumber : Perhitungan)

- Menghitung Banyak Kelas

$$
\begin{aligned}
K \quad & =1+3,322 \log n \\
& =1+3,322 \log 10 \\
& =4,322
\end{aligned}
$$

Jadi banyak kelas adalah 4 kelas 
- $\quad$ Menghitung Nila $\mathrm{E}_{\mathrm{f}}$

$$
\begin{aligned}
E_{f} & =\frac{n}{K} \\
& =\frac{10}{4} \\
& =2,5
\end{aligned}
$$

- Nilai Batas Tiap Kelas

$$
\begin{aligned}
\Delta x & =\frac{x_{i=1}-x_{i=10}}{k-1} \\
& =\frac{151-46}{3,322} \\
& =31,51 \\
x_{\text {awal }} & =x_{i=10}-\frac{1}{2} \Delta x \\
& =46-\frac{1}{2} 31,51 \\
& =28,67
\end{aligned}
$$

Tabel 13. Perhitungan $X^{2} C_{r}$

\begin{tabular}{|c|c|c|c|c|c|c|}
\hline \multicolumn{2}{|c|}{$\begin{array}{c}\text { Nilai Batas Tiap } \\
\text { Kelas }\end{array}$} & $\mathbf{E}_{\mathbf{f}}$ & $\mathbf{O}_{\mathbf{f}}$ & $\begin{array}{c}\mathbf{E}_{\mathbf{f}}- \\
\left.\mathbf{O}_{\mathbf{f}}\right)^{\mathbf{2}}\end{array}$ & $\mathbf{X}^{\mathbf{2}} \mathbf{C}_{\mathbf{r}}$ \\
\hline 28,67 & $<\mathrm{x}<$ & 60,18 & 2,3 & 1 & 1,71 & 0,742 \\
\hline 60,18 & $<\mathrm{x}<$ & 91,69 & 2,3 & 2 & 0,10 & 0,041 \\
\hline 91,69 & $<\mathrm{x}<$ & 123,21 & 2,3 & 2 & 0,10 & 0,041 \\
\hline 123,21 & $<\mathrm{x}<$ & 154,72 & 2,3 & 5 & 7,24 & 3,138 \\
\hline \multicolumn{3}{|c|}{ Jumlah } & $\mathbf{1 0}$ & $\mathbf{1 0}$ & $\boldsymbol{x}^{2}{ }_{\text {Hitung }}$ & $\mathbf{3 , 9 6 2}$ \\
\hline
\end{tabular}

(Sumber : Perhitungan)

- Derajat Kebebasan

$$
\begin{aligned}
D_{k} \quad & =K-(R+1) \\
& =4-(1+1) \\
& =2
\end{aligned}
$$

Maka untuk $x^{2}$ tabel untuk $\mathrm{Dk}=2$ dan signifikan 0,05 diperoleh 5,991 (tabel nilai kritis chi square)

$$
x_{\text {Hitung }}^{2}=3,962
$$$$
x_{\text {tabel }}^{2}=5,991
$$

Maka metode distribusi gumbel dapat diterima karena $x_{\text {Hitung }}^{2}<x^{2}$ tabel

2.Uji Smirnov Kolmogorov Terhadap Distribusi Gumbel
Tabel 14 Perhitungan Uji Smirnov Kolmogorov

\begin{tabular}{|c|c|c|c|c|c|c|c|}
\hline $\boldsymbol{x}_{\boldsymbol{i}}$ & $\mathbf{m}$ & $\mathbf{P}(\mathbf{x})$ & $\mathbf{P}(\mathbf{x}<)$ & $\mathbf{F}_{\mathbf{t}}$ & $\mathbf{P}^{\prime}(\mathbf{x})$ & $\mathbf{P}^{\prime}(\mathbf{x}<)$ & $\mathbf{D}$ \\
\hline 151 & 1 & 0,091 & 0,909 & 1,10 & 0,883 & 0,117 & 0,792 \\
\hline 146 & 2 & 0,182 & 0,818 & 0,95 & 0,842 & 0,158 & 0,660 \\
\hline 140 & 3 & 0,273 & 0,727 & 0,78 & 0,793 & 0,207 & 0,520 \\
\hline 135 & 4 & 0,364 & 0,636 & 0,63 & 0,754 & 0,246 & 0,390 \\
\hline 134 & 5 & 0,455 & 0,545 & 0,60 & 0,742 & 0,258 & 0,287 \\
\hline 115 & 6 & 0,545 & 0,455 & 0,04 & 0,529 & 0,471 & $-0,01$ \\
\hline 95 & 7 & 0,636 & 0,364 & $-0,5$ & 0,286 & 0,714 & $-0,35$ \\
\hline 89 & 8 & 0,727 & 0,273 & $-0,7$ & 0,207 & 0,793 & $-0,52$ \\
\hline 85 & 9 & 0,818 & 0,182 & $-0,8$ & 0,181 & 0,819 & $-0,63$ \\
\hline 46 & 10 & 0,909 & 0,091 & $-1,9$ & 0,024 & 0,976 & $-0,88$ \\
\hline
\end{tabular}

\begin{tabular}{|c|c|c|c|c|c|c|}
\hline No & $\begin{array}{c}\text { Tahu } \\
\text { n }\end{array}$ & $\log \mathbf{x}_{\mathbf{i}}$ & $\begin{array}{c}\left(\log x_{i}-\right. \\
\left.\log x_{r}\right) \\
\end{array}$ & $\begin{array}{c}\left(\log x_{i}-\right. \\
\left.\log x_{r}\right)^{2} \\
\end{array}$ & $\begin{array}{l}\left(\log x_{i}-\right. \\
\left(\log x_{r}\right)^{3}\end{array}$ & $\begin{array}{c}\left(\log x_{i}-\right. \\
\left.\log x_{r}\right)^{4}\end{array}$ \\
\hline 1 & 09 & 2,15 & 0,11343957 & 0,0128685 & 0,0014598 & 0,0001655 \\
\hline 2 & 10 & 2,16 & 0,13166439 & 0,0173355 & 0,0022824 & 0,0003005 \\
\hline 3 & 11 & 2,13 & 0,09764530 & 0,009 & 0,00 & 0,00 \\
\hline 4 & 12 & 1,66 & $-0,36993063$ & 0,1368486 & $-0,050$ & 0,0187275 \\
\hline 5 & 13 & 1,95 & $-0,08329845$ & 0,0069386 & $-0,0005779$ & 0,0000481 \\
\hline 6 & 14 & 2,18 & 0,14628848 & 0,0214003 & 0,0031306 & 0,0004579 \\
\hline 7 & 15 & 1,98 & $-0,05496485$ & 0,0030211 & $-0,0001660$ & 0,0000091 \\
\hline 8 & 16 & 2,06 & 0,02800937 & 0,0007845 & 0,0000219 & 0,0000006 \\
\hline 9 & 17 & 2,13 & 0,09441633 & 0,0089144 & 0,0008416 & 0,0000794 \\
\hline 10 & 18 & 1,93 & $-0,10326953$ & 0,0106645 & $-0,0011013$ & 0,0001137 \\
\hline \multicolumn{2}{|r|}{$\Sigma$} & 20,3 & 0,0000000 & $\mathbf{0 , 2 2 8 3 1 0 9}$ & $-0,0438023$ & 0,0199936 \\
\hline
\end{tabular}

(Sumber : Perhitungan)

Berdasarkan tabel nilai kritis untuk uji smirnov kolmogorov
$\mathrm{n} \quad=10$ tahun
$\mathrm{D}_{\mathrm{o}}(1 \%) \quad=0,486$
$\mathrm{D}_{\mathrm{o}}(5 \%) \quad=0,409$

Maka metode distribusi Gumbel dapat diterima karena $\mathrm{D}_{\max }<\mathrm{D}_{\mathrm{o}}(5 \%)$.

\section{E. Perhitungan Curah Hujan Rencana Distribusi Log Normal}

Tabel 15 Perhitungan Curah Hujan Rencana Distribusi Log Normal

(Sumber : Perhitungan)

- $\quad$ Rata-rata

$$
\log x_{r}=\frac{\sum \log x_{i}}{n}=\frac{20,33}{10}=2,033
$$


- $\quad$ Standar Deviasi

$$
S_{d}=\sqrt{\frac{\sum\left(\log x_{i}-\log x_{r}\right)^{2}}{n-1}}=\sqrt{\frac{0,228310983}{9}}=0,159273
$$

- Koefisien Variasi

$$
C_{v}=\frac{S_{d}}{x_{r}}=\frac{0,159273}{2,033}=0,078356
$$

- $\quad$ Koefisien Skewness

$$
C_{s}=\frac{n \sum\left(\log x_{i}-\log x_{r}\right)^{3}}{(n-1)(n-2)(s d)^{3}}=\frac{-0,43802332}{0,29091}=-1,5057
$$

- Koefisien Kurtosis

$$
C_{k}=\frac{n^{2} \sum\left(\log x_{i}-\log x_{r}\right)^{4}}{(n-1)(n-2)(n-3)(s d)^{4}}=\frac{1,9994}{0,3243}=6,16443
$$

1.Uji Chi Kuadrat Terhadap Distribusi Log Normal

Tabel 16 Perhitungan Uji Chi Kuadrat Terhadap Distribusi Log Normal

\begin{tabular}{|c|c|c|}
\hline No & Tahun & $\boldsymbol{L o g} \boldsymbol{x}_{\boldsymbol{i}}$ \\
\hline 1 & 2009 & 2,18 \\
\hline 2 & 2010 & 2,16 \\
\hline 3 & 2011 & 2,15 \\
\hline 4 & 2012 & 2,13 \\
\hline 5 & 2013 & 2,13 \\
\hline 6 & 2014 & 2,06 \\
\hline 7 & 2015 & 1,98 \\
\hline 8 & 2016 & 1,95 \\
\hline 9 & 2017 & 1,93 \\
\hline 10 & 2018 & 1,66 \\
\hline
\end{tabular}

(Sumber : Perhitungan)

- Menghitung Banyak Kelas

$$
\begin{aligned}
K \quad & =1+3,322 \log n \\
& =1+3,322 \log 10 \\
& =4,322
\end{aligned}
$$

Jadi banyak kelas adalah 4 kelas

- $\quad$ Menghitung Nila $E_{\mathrm{f}}$

$$
\begin{aligned}
E_{f} & =\frac{n}{K} \\
& =\frac{10}{4} \\
& =2,5
\end{aligned}
$$

- Nilai Batas Tiap Kelas

$$
\begin{aligned}
\Delta x \quad & =\frac{x_{i=1}-x_{i=10}}{k-1} \\
& =\frac{2,18-1,66}{3,322} \\
& =0,15 \\
x_{\text {aval }} & =x_{i=10}-\frac{1}{2} \Delta x \\
& =1,66-\frac{1}{2} 0,15 \\
& =1,59
\end{aligned}
$$

Tabel 17. Perhitungan $\mathrm{X}^{2} \mathrm{C}_{\mathrm{r}}$

\begin{tabular}{|c|c|c|c|c|c|c|}
\hline \multicolumn{2}{|c|}{$\begin{array}{c}\text { Nilai Batas Tiap } \\
\text { Kelas }\end{array}$} & $\mathbf{E}_{\mathrm{f}}$ & $\mathbf{O}_{\mathrm{f}}$ & $\begin{array}{c}\mathbf{( E}_{\mathrm{f}}-\mathbf{2} \\
\left.\mathbf{O}_{\mathrm{f}}\right)^{\mathbf{2}}\end{array}$ & $\mathbf{X}^{\mathbf{2}} \mathbf{C}_{\mathbf{r}}$ \\
\hline 1,59 & $<\mathrm{x}<$ & 1,74 & 2,3 & 1 & 1,71 & 0,742 \\
\hline 1,74 & $<\mathrm{x}<$ & 1,90 & 2,3 & 0 & 5,33 & 2,308 \\
\hline 1,90 & $<\mathrm{x}<$ & 2,05 & 2,3 & 3 & 0,48 & 0,207 \\
\hline 2,05 & $<\mathrm{x}<$ & 2,21 & 2,3 & 6 & 13,63 & 5,904 \\
\hline \multicolumn{3}{|c|}{ Jumlah } & $\mathbf{1 0}$ & $\mathbf{1 0}$ & $\boldsymbol{x}^{2}{ }_{\text {Hitung }}$ & $\mathbf{9 , 1 6 1}$ \\
\hline
\end{tabular}

(Sumber : Perhitungan)

- Derajat Kebebasan

$$
\begin{aligned}
D_{k} \quad & =K-(R+1) \\
& =4-(2+1) \\
& =1
\end{aligned}
$$

Maka untuk $x^{2}$ tabel untuk $\mathrm{Dk}=1$ dan signifikan 0,05 diperoleh 3,891 (tabel nilai kritis chi square) $x^{2}{ }_{\text {Hitung }}=1,200$

$x^{2}{ }_{\text {tabel }}=3,891$

Maka metode distribusi log normal dapat diterima karena $x^{2}{ }_{\text {Hitung }}<x^{2}$ tabel

2.Uji Smirnov Kolmogorov Terhadap Distribusi Log Normal

Tabel 18 Perhitungan Uji Smirnov Kolmogorov

\begin{tabular}{|c|c|c|c|c|c|c|c|}
\hline $\boldsymbol{x}_{i}$ & $\mathbf{M}$ & $\mathbf{P}(\mathbf{x})$ & $\mathbf{P}(\mathbf{x}<)$ & $\mathbf{F}_{\mathbf{t}}$ & $\mathbf{P}^{\prime}(\mathbf{x})$ & $\mathbf{P}^{\prime}(\mathbf{x}<)$ & $\mathbf{D}$ \\
\hline 2,18 & 1 & 0,091 & 0,909 & 0,92 & 0,843 & 0,157 & 0,752 \\
\hline 2,16 & 2 & 0,182 & 0,818 & 0,83 & 0,819 & 0,181 & 0,637 \\
\hline 2,15 & 3 & 0,273 & 0,727 & 0,71 & 0,783 & 0,217 & 0,510 \\
\hline 2,13 & 4 & 0,364 & 0,636 & 0,61 & 0,763 & 0,237 & 0,399 \\
\hline 2,13 & 5 & 0,455 & 0,545 & 0,59 & 0,738 & 0,262 & 0,283 \\
\hline 2,06 & 6 & 0,545 & 0,455 & 0,18 & 0,589 & 0,411 & 0,044 \\
\hline 1,98 & 7 & 0,636 & 0,364 & $-0,3$ & 0,353 & 0,647 & $-0,28$ \\
\hline 1,95 & 8 & 0,727 & 0,273 & $-0,5$ & 0,281 & 0,719 & $-0,44$ \\
\hline 1,93 & 9 & 0,818 & 0,182 & $-0,6$ & 0,247 & 0,753 & $-0,57$ \\
\hline 1,66 & 10 & 0,909 & 0,091 & $-2,3$ & 0,008 & 0,992 & $-0,90$ \\
\hline \multicolumn{7}{|c|}{} \\
\end{tabular}

(Sumber : Perhitungan) 
Berdasarkan tabel nilai kritis untuk uji smirnov kolmogorov

$$
\begin{array}{ll}
\mathrm{n}=10 \text { tahun } \\
\mathrm{D}_{\mathrm{o}}(1 \%) & =0,486 \\
\mathrm{D}_{\mathrm{o}}(5 \%) & =0,409
\end{array}
$$

Maka metode distribusi log normal dapat diterima karena $\mathrm{D}_{\max }<\mathrm{D}_{\mathrm{o}}(5 \%)$

\section{F.Pemilihan Distribusi}

Dalam pemilihan distribusi yang akan digunakan untuk perhitungan selanjutnya digunakan tabel pengujian sebagai berikut :

Tabel 19 Berikut ini adalah tabel untuk pemilihan distribusi

\begin{tabular}{|c|c|c|c|}
$\begin{array}{c}\text { Hasil } \\
\text { Distribusi }\end{array}$ & Syarat & Perhitungan & Kesimpulan \\
\hline Normal & $\mathrm{Cs}=0$ & $\mathrm{Cs}=-0,82$ & Tidak \\
& $\mathrm{Ck}=3$ & $\mathrm{Ck}=3,88$ & memenuhi \\
\hline & $\mathrm{Cs} \leq$ & & \\
Gumbel & 1,1396 & $\mathrm{Cs}=-0,82$ & Memenuhi \\
& $\mathrm{Ck} \leq$ & $\mathrm{Ck}=3,88$ & \\
& 5,4002 & & \\
\hline
\end{tabular}

(Sumber : Perhitungan)

Maka metode distribusi yang memenuhi persyaratan untuk digunakan dalam perhitungan selanjutnya adalah metode distribusi gumbel.

$$
\begin{array}{cl}
\begin{array}{c}
\text { G.Perhitungan Curah Hujan Periode } \\
\text { Ulang } \\
x_{r}
\end{array} & =113,6 \\
S_{d} & =33,9286 \\
a & =\frac{1,283}{33,9286}=0,0378 \\
& =x_{r}-\left(0,455 \cdot S_{d}\right) \\
x_{0} \quad & 113,6-(0,455.33,9286) \\
& =98,162 \\
y & =a\left(x_{t}-x_{o}\right) \\
& =0,0378\left(x_{t}-98,162\right) \\
& =0,0378 x_{t}-3,7105 \\
x_{t} & =\frac{y+3,7105}{0,0378}
\end{array}
$$

\begin{tabular}{|c|c|c|c|c|}
\hline $\begin{array}{c}\text { Deskripsi } \\
\text { Daerah }\end{array}$ & $\begin{array}{c}\text { Luas } \\
\left(\mathbf{m}^{2}\right)\end{array}$ & $\operatorname{Luas}\left(\mathrm{km}^{2}\right)$ & \begin{tabular}{|c|} 
Koefisien \\
Limpasan
\end{tabular} & c \\
\hline Permukiman & $\begin{array}{c}10.982 \\
\mathrm{~m}^{2}\end{array}$ & $\begin{array}{c}0,01098 \\
\mathrm{~km}^{2}\end{array}$ & 0,6 & 0,37804 \\
\hline Jalan & $5.726 \mathrm{~m}^{2}$ & $\begin{array}{c}0,00573 \\
\mathrm{~km}^{2}\end{array}$ & 0,95 & 0,31209 \\
\hline Taman & $720 \mathrm{~m}^{2}$ & $\begin{array}{c}0,00072 \\
\mathrm{~km}^{2}\end{array}$ & 0,25 & 0,01033 \\
\hline \multicolumn{4}{|c|}{ Jumlah Koefisein Aliran (c) } & 0,70045 \\
\hline
\end{tabular}

1. Periode Ulang 2 Tahun

$$
\begin{aligned}
y & =0,366 \\
x_{t} & =\frac{y+3,7105}{0,0378} \\
& =\frac{0,366+3,7105}{0,0378}
\end{aligned}
$$$$
=107,844
$$

2. Periode Ulang 5 Tahun

$$
\begin{aligned}
y & =1,51 \\
x_{t} & =\frac{y+3,7105}{0,0378} \\
& =\frac{1,51+3,7105}{0,0378} \\
& =138,108
\end{aligned}
$$

3. Periode Ulang 10 Tahun

$$
\begin{aligned}
y & =2,25 \\
x_{t} & =\frac{y+3,7105}{0,0378} \\
& =\frac{2,25+3,7105}{0,0378} \\
& =157,685
\end{aligned}
$$

Untuk Perhitungan intensitas hujan dengan menggunakan rumus mononobe digunakan periode ulang 10 tahun $x_{t}=68,4468$

\section{H.Perhitungan Debit Aliran}

Tabel 20. Tabel Perhitungan Nilai Koefisien Aliran

\section{Menghitung Dimensi Saluran Sekunder}

Langkah selanjutnya menghitung waktu konsentrasi dan koefisien tampung pada daerah aliran sebagai berikut :

$$
\begin{array}{ll}
L_{0} & =187 m \\
L_{i} & =312 m \\
\Delta H & =0,12 m
\end{array}
$$


1. Kemiringan Permukaan Tanah yang Dilalui Aliran Diatasnya.

$$
\begin{aligned}
S_{0} \quad & =\frac{\Delta H}{L_{0}} \\
& =\frac{0,12}{187} \\
& =0,000642
\end{aligned}
$$

2. Inlet Time Kesaluran Terdekat

$$
\begin{aligned}
T_{0} \quad & =0,0195\left(\frac{L_{0}}{\sqrt{S_{0}}}\right)^{0,77} \\
& =0,0195\left(\frac{187}{\sqrt{0,000642}}\right)^{0,77} \\
& =18,5546 \text { menit } \\
& =0,30924 \text { jam }
\end{aligned}
$$

3. Conduit Time Sampai Ketempat Pengukuran

$$
\begin{aligned}
T_{d} & =\frac{1}{3600} \times \frac{L_{i}}{v} \\
& =\frac{1}{3600} \times \frac{312}{1,5} \\
& =0,05778 \mathrm{jam}
\end{aligned}
$$

4. Waktu Konsentrasi

$$
\begin{aligned}
T_{c} \quad & =T_{0}+T_{d} \\
& =0,30924+0,05778 \\
& =0,36702 \mathrm{jam}
\end{aligned}
$$

5. Koefisien Tampungan

$$
\begin{aligned}
C_{s} & =\frac{2 T_{c}}{2 T_{c}+T_{d}} \\
& =\frac{2.0,36702}{2.0,36702+0,05778} \\
& =0,92703 \mathrm{jam}
\end{aligned}
$$

6. Intensitas Hujan

$$
\begin{aligned}
I \quad & =\frac{R_{24}}{24} \times\left(\frac{24}{T_{c}}\right)^{2 / 3} \\
& =\frac{157,685}{24} \times\left(\frac{24}{0,36702}\right)^{2 / 3} \\
& =106,641 \mathrm{~mm} / \mathrm{jam}
\end{aligned}
$$

7. Debit Puncak dengan Kala Ulang 10 Tahun

$$
\begin{aligned}
Q \quad & =0,278 \times C \times C_{s} \times I \times A \\
& =0,278 \times 0,70045 \times 0,92703 \times 106,641 \times 0,01743 \\
& =0,3355 \mathrm{~m}^{3} / \mathrm{dtk}
\end{aligned}
$$

\section{J.Analisa Luas Penampang Saluran}

Telah di dapat dari perhitungan dan survey lapangan, antara lain

$$
\begin{aligned}
Q & =0,3355 \mathrm{~m}^{3} / d t k \\
V & =0,584 \mathrm{~m} / d t k
\end{aligned}
$$

1. Luas penampang aliran

$$
\begin{aligned}
A \quad & =\frac{Q}{V} \\
& =\frac{0,3355}{0,584} \\
& =0,5742 \mathrm{~m}^{2}
\end{aligned}
$$

2. Lebar dan tinggi penampang aliran Untuk persyaratan penampang persegi panjang yang ekonomis adalah :

$$
\begin{array}{ll}
A & =B y \\
B & =2 y \\
0,5742 & =B y
\end{array}
$$

Substitusi persamaan 1 ke persamaan 2

$$
\begin{array}{ll}
0,5742 & =2 y^{2} \\
y^{2} & =\frac{0,5742}{2} \\
y^{2} & =0,2871 \\
y & =\sqrt{0,2871} \\
& =0,5358 \mathrm{~m} \\
& =55 \mathrm{~cm} \\
B & =2 y \\
& =2.0,5358 \\
& =1,07 \mathrm{~m}
\end{array}
$$

3. Keliling Basah

$=B+2 y$

$=1,07+(2 \times 0,5358)$

$=2,142 \mathrm{~m}$

4. Jari-jari Hidrolik

$$
\begin{aligned}
R \quad & =\frac{A}{P} \\
& =\frac{0,5742}{2,142} \\
& =0,268 \mathrm{~m}
\end{aligned}
$$



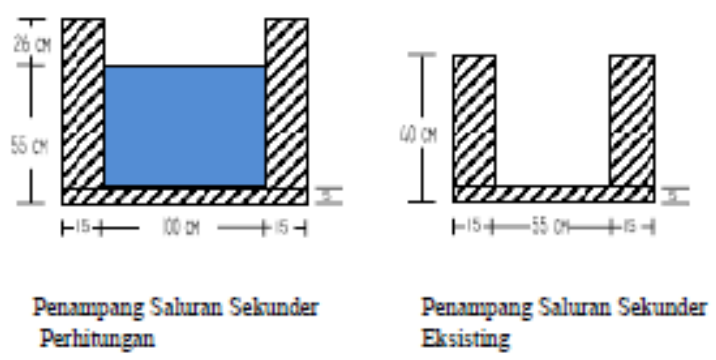

Gambar 4. Perbandingan Antara Penampang Eksisting dengan Penampang Hasil Perhitungan

\section{K.Menghitung Dimensi Saluran Tersier}

$$
\begin{array}{ll}
L_{0} & =156 m \\
L_{i} & =526 m \\
\Delta H & =0,032 m
\end{array}
$$

1. Kemiringan Permukaan Tanah yang Dilalui Aliran Diatasnya.

$$
\begin{aligned}
S_{0} \quad & =\frac{\Delta H}{L_{0}} \\
& =\frac{0,032}{156} \\
& =0,0002
\end{aligned}
$$

2. Inlet Time Kesaluran Terdekat

$$
\begin{aligned}
T_{0} \quad=0,0195\left(\frac{L_{0}}{\sqrt{S_{0}}}\right)^{0,77} \\
=0,0195\left(\frac{156}{\sqrt{0,0002}}\right)^{0,77} \\
=25,2839 \text { menit } \\
=0,42139 \text { jam }
\end{aligned}
$$

3. Conduit Time Sampai Ketempat Pengukuran

$$
\begin{aligned}
T_{d} & =\frac{1}{3600} \times \frac{L_{i}}{v} \\
& =\frac{1}{3600} \times \frac{526}{1,5} \\
& =0,09741 \mathrm{jam}
\end{aligned}
$$

4. Waktu Konsentrasi

$$
\begin{aligned}
T_{c} \quad & =T_{0}+T_{d} \\
& =0,42139+0,09741 \\
& =0,51879 \mathrm{jam}
\end{aligned}
$$

5. Koefisien Tampungan

$$
\begin{aligned}
C_{s} & =\frac{2 T_{c}}{2 T_{c}+T_{d}} \\
& =\frac{2.0,51879}{2.0,51879+0,09741} \\
& =0,91418 \mathrm{jam}
\end{aligned}
$$

6. Intensitas Hujan

$$
\begin{aligned}
I \quad & =\frac{R_{24}}{24} \times\left(\frac{24}{T_{c}}\right)^{2 / 3} \\
& =\frac{157,685}{24} \times\left(\frac{24}{0,51879}\right)^{2 / 3} \\
& =84,669 \mathrm{~mm} / \mathrm{jam}
\end{aligned}
$$

7. Debit Puncak dengan Kala Ulang 10 Tahun

$Q \quad=0,278 \times C \times C_{s} \times I \times A$

$=0,278 \times 0,70045 \times 0,92703 \times 84,669 \times 0,01743$

$=0,2664 \mathrm{~m}^{3} / d t k$

\section{L.Analisa Luas Penampang Saluran}

Telah di dapat dari perhitungan dan survey lapangan, antara lain

$$
\begin{aligned}
Q & =0,2664 \mathrm{~m}^{3} / \mathrm{dtk} \\
V & =1,06 \mathrm{~m} / \mathrm{dtk}
\end{aligned}
$$

1. Luas penampang aliran

$$
\begin{aligned}
A \quad & =\frac{Q}{V} \\
& =\frac{0,2664}{1,06} \\
& =0,2513 \mathrm{~m}^{2}
\end{aligned}
$$

2. Lebar dan tinggi penampang aliran Untuk persyaratan penampang persegi panjang yang ekonomis adalah :

$$
\begin{array}{ll}
A & =B y \\
B & =2 y \\
0,2513 & =B y
\end{array}
$$

Substitusi persamaan 1 ke persamaan 2 


$\begin{array}{ll}0,2513 & =2 y^{2} \\ y^{2} & =\frac{0,2513}{2} \\ y^{2} & =0,1257 \\ y & =\sqrt{0,1257} \\ & =0,3545 \mathrm{~m} \\ & =35 \mathrm{~cm} \\ B & =2 y \\ & =2.0,35 \\ & =0,70 \mathrm{~m}\end{array}$

3. Keliling Basah

$$
\begin{aligned}
P & =B+2 y \\
& =0,70+(2 \times 0,35) \\
& =1,4 \mathrm{~m}
\end{aligned}
$$

4. Jari-jari Hidrolik

$$
\begin{aligned}
R \quad & =\frac{A}{P} \\
& =\frac{0,2513}{1,4} \\
& =0,1795 \mathrm{~m}
\end{aligned}
$$

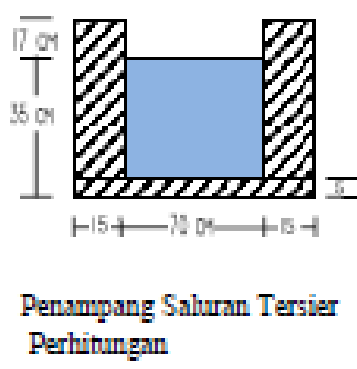

Gambar 4. Perbandingan Antara Penampang Eksisting dengan Penampang Hasil Perhitungan pada Saluran Tersier
Jadi menurut hasil perhitungan dari data curah hujan, 10 tahun mendatang saluran drainase tidak mampu menampung debit aliran air.

\section{DAFTAR PUSTAKA}

Kodiatie, Robert, 2003, “Manajemen Rekayasa Infrastruktur", Penerbit : Pustaka Pelajar. Yogjakarta.

Sobriyah dan Wignyasukarto, Budi, 2001, "Peran Serta Masyarakat dalam Pengendalian Banjir untuk Mendukung Pelaksanaan Otonomi Daerah", Malang.

Suripin, 2004, " Sistem Drainase di Daerah Pemukimam yang Berkelanjutan", Penerbit Andi. Yogyakarta

Balai Lingkungan Permukiman, 2008. Drainase Pemukiman" ,Bandung

Kodoatie, Robert, 2003, “Manajemen Rekayasa Infrastruktur", Penerbit : Pustaka Pelajar. Yogjakarta.

Sobriyah dan Wignyasukarto, Budi, 2001, "Peran Serta Masyarakat dalam Pengendalian Banjir untuk Mendukung Pelaksanaan Otonomi Daerah", Malang.

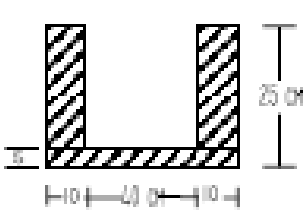

Soewarno, 1995, "Hidrologi Teknik" Erlangga. Jakarta

\section{Kesimpulan}

Dari hasil observasi lapangan dan perhitungan, maka didapatkan kesimpulan sebagai berikut :

1. Didapat hasil survey lapangan ukuran dimensi saluran eksisting adalah :

Saluran Sekunder $\quad=40 \mathrm{~cm} \times 55 \mathrm{~cm}$

Saluran Tersier $\quad=25 \mathrm{~cm} \mathrm{x} 40 \mathrm{~cm}$

2. Dan dari hasil analisa perhitungan didapat ukuran dimensi saluran adalah :

Saluran Sekunder $\quad=81 \mathrm{~cm} \times 100 \mathrm{~cm}$

Saluran Tersier $\quad=52 \mathrm{~cm} \times 70 \mathrm{~cm}$ 